\title{
The time-dependent localization of Ki 67 antigen-positive cells in human skin wounds
}

\author{
P. Betz ${ }^{1}$, A. Nerlich ${ }^{2}$, J.Wilske ${ }^{1}$, J. Tübel ${ }^{1}$, R.Penning ${ }^{1}$, and W. Eisenmenger ${ }^{1}$ \\ Departments of Legal Medicine ${ }^{1}$ and Pathology ${ }^{2}$, University of Munich, Frauenlobstrasse 7a, D-80337 Munich, Germany
}

Received January 28, 1993 / Received in revised form March 18, 1993

\begin{abstract}
Summary. A total of 77 human skin wounds with a postinfliction interval between $3 \mathrm{~h}$ and 7 months were investigated and the proliferation marker antigen Ki67 was visualized in paraffin sections using a specific monoclonal antibody (MIB). The re-built epidermal layer covering the former lesional area showed only a few basal cells positively staining for $\mathrm{Ki} 67$ antigen. No enhanced reactivity was found when compared to uninjured skin. In basal cells of the epidermis adjacent to the wound area, however, varying numbers of positive cells occurred, but no information useful for a reliable time estimation of skin wounds could be obtained due to the considerable variability in the number of $\mathrm{Ki} 67$ positive epidermal basal cells found in non-damaged skin. Fibroblastic cells in the wound area revealed an increased number of Ki 67-positive sites which could first be detected in a 1.5day-old skin lesion. Positive results could be obtained in every specimen investigated after a post-infliction interval of 6 days up to 1.5 months. Only the scar tissue of the oldest wound examined (wound age 7 months) revealed no increase in the number of positively staining fibroblasts. Therefore, positive results indicate a wound age of at least approximately 1.5 days and the lack of an increased number of positive fibroblastic cells in a sufficient number of specimens indicates at a wound age of less than 6 days, but cannot totally exclude longer postinfliction intervals.
\end{abstract}

Key words: Ki 67 - Wound age - Immunohistochemistry

Zusammenfassung. In Paraffinschnitten von 77 menschlichen Hautwunden mit einer Überlebenszeit zwischen 3 Std und 7 Monaten wurde das Ki 67-Antigen mit einem monoklonalen Antikörper (MIB) immunhistochemisch dargestellt. Die neugebildete Epidermis zeigte lediglich einzelne, positiv reagierende Keratinozyten, eine verstärkte Reaktivität im Vergleich zu unverletzten Hautarealen war nicht feststellbar. Die epidermalen Basalzellschichten, die dem ursprünglichen Epitheldefekt benachbart waren, wiesen jedoch eine unterschiedlich aus-

Correspondence to: $\mathrm{P}$. Betz geprägte Anfärbbarkeit auf. Eine Aussage zum Wundalter war anhand der Zahl positiv reagierender Basalzellen wegen der beträchtlichen intra- wie auch interindividuellen Streubreite der Befunde nicht möglich. Eine relevant erhöhte Zahl positiv reagierender fibroblastärer Zellen im Wundgebiet verglichen mit unverletzter Dermis trat erstmals in einer 1,5 Tage überlebten Wunde auf und war in allen untersuchten Wunden ab 6 Tagen Überlebenszeit bis zu einem Wundalter von 1,5 Monaten zu beobachten. Lediglich die älteste untersuchte Läsion (Wundalter 7 Monate) zeigte keine relevante Zahl Ki 67-exprimierender Fibroblasten im Narbengewebe. Positive Befunde belegen somit eine Überlebenszeit von mindestens 1,5 Tagen. Das Fehlen einer erhöhten Zahl positiv anfärbbarer fibroblastärer Zellen in einer ausreichenden Anzahl von Präparaten weist auf ein Wundalter unter ca. 6 Tagen hin, kann ein solches allerdings nicht mit letzter Sicherheit beweisen.

Schlüsselwörter: Ki 67 - Wundalter - Immunhistochemie

\section{Introduction}

During the healing of skin wounds cellular infiltration and the synthesis of various extracellular matrix proteins occur as important mechanisms of tissue remodeling. However, reparative changes also include the proliferation of local resting cells. By the use of immunohistochemical techniques the specific detection of cell infiltration and matrix synthesis can be monitored. In addition, the immunolocalization of the nuclear $\mathrm{Ki} 67$ antigen which is expressed by cells in the $G_{1}, G_{2}, S$, and $M$ phases of the cell cycle $[10,11]$ can be performed by a monoclonal antibody. The use of an immunohistochemical analysis of cell proliferation by detection of this nuclear proliferating antigen for a forensically applicable time estimation of human skin wounds has not yet been investigated.

Therefore, in the present study the Ki 67 antigen was visualized in human skin lesions to prove whether the 
immunohistochemical detection of this protein can provide information useful for a wound age estimation in forensic medicine.

\section{Material and methods}

A total of 77 human skin wounds (primarily healing lacerations and stab wounds after surgical treatment, surgical wounds) with a post-infliction interval between $3 \mathrm{~h}$ and 7 months were investigated. The specimens were obtained from individuals aged between 21 and 75 years (average age 47 years) during autopsy as previously described [1]. The Ki67 antigen was visualized in paraffin sections using a monoclonal antibody (MIB 1) according to the instructions of the commercial supplier (Fa. Dianova, Hamburg, Germany) by the APAAP-method [6].

In addition, undamaged skin from the same patients as well as specimens without the inclusion of the primary antibody were stained and acted as controls.

The sections were evaluated by light microscopy (magnification $100 \times$ ) using a 100 -point grid (original size $1 \mathrm{~cm}^{2}$ ). The numbers of Ki 67 positive basal cells in parts of the epidermal layer with a length of $0.002 \mathrm{~cm}$ were estimated and compared with those found in correspondingly sized areas with $0.002 \mathrm{~cm}$ distances from the wound edge or central parts of the re-built epidermis.

Furthermore, the numbers of positively staining fibroblastic cells per $0.0001 \mathrm{~cm}^{2}$ in uninjured skin was estimated in at least 5 randomly selected microscope fields and compared with those found in the lesional area/granulation tissue of the same skin wound.

\section{Results}

\section{Normal skin}

In uninjured skin a variable number of positively reacting basal cells with absolute values ranging from $0-17$ cells per $0.002 \mathrm{~cm}$ length of the epidermis could be found indicating a considerable interindividual variability. The mean value ranged between $3.2 \pm 2.3$ and $4.1 \pm 3.9$ cells (Fig. 3).

Single positively reacting fibroblasts were found in the dermis of only a very few specimens (maximum value 2 cells per $0.0001 \mathrm{~cm}^{2}$ ). Most specimens of uninjured skin, however, contained no positively staining fibroblastic cells.

Furthermore, a positive staining was also observed in basal cell layers of skin appendages like hair follicles and sweat gland ducts and - with a somewhat reduced staining intensity - in some lymphocytes of lymphatic infiltrates occasionally present in the dermis. No relevant positive reactivity could be found in nerve or muscle cells.

In some specimens obtained from older individuals, smaller numbers of positively reacting dermal fibroblasts and basal cells of the epidermis could be found, but relevant differences exceeding the considerable interindividual variability could not be established.

\section{Skin wounds}

Epidermal layer. In central parts of the re-built epidermis covering the wound area no relevant numbers of Ki 67 positive cells were observed.

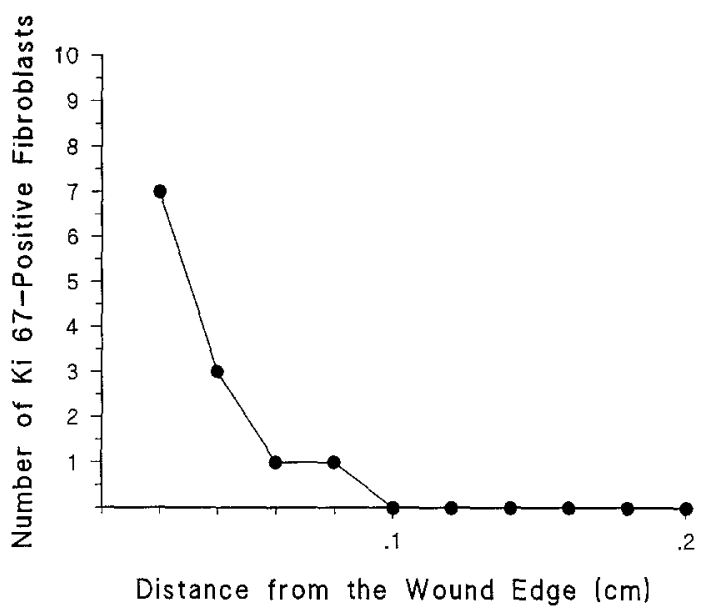

Fig. 1. 11-day-old skin wound (male, 27 years, head wound)

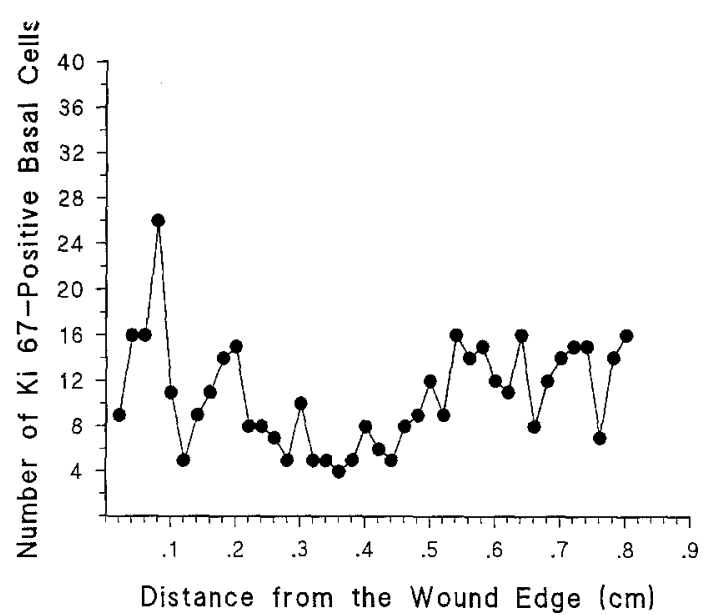

Fig. 2. 4-day-old skin wound (female, 70 years, head wound)

In $80 \%$ ( 37 out of 46 cases) of the specimens showing at least the onset of keratinocyte migration and a postinfliction interval of 3 days or more different numbers of Ki 67 positive basal cells occurred in epidermal layers adjacent to the lesional area showing a wave-like increase and decrease in the number with advancing distance from the wound margins or the central parts of the rebuilt epidermis. Considerably elevated numbers of positive basal cells (maximum value 28 cells per $0.002 \mathrm{~cm}$ of the epidermal layer), however, were found also in some specimens in distances exceeding more than $0.5 \mathrm{~cm}$ (Fig. 2). The remaining $20 \%$ (9 out of 46 cases) showed also increasing and decreasing values dependent on the distance from the wound area but no relevantly increased numbers when compared to uninjured skin specimens or parts of the same skin wound with a distance of more than $0.5 \mathrm{~cm}$ were observed (Fig. 4).

No correlation between the numbers of positively stained epidermal basal cells and the post-infliction interval useful for a forensically applicable wound age estimation could be established due to the considerable variabilities detectable in one and the same specimen, in different skin wounds and in uninjured skin. 


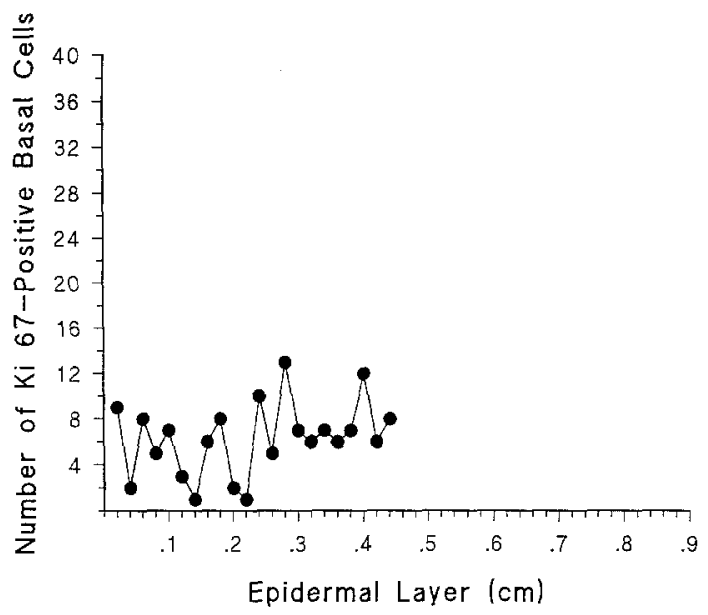

Fig. 3. Uninjured skin (female, 45 years)

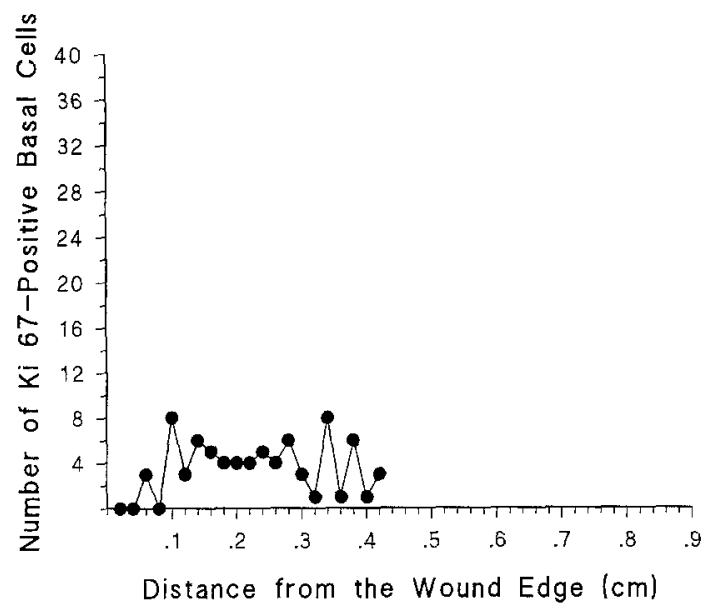

Fig. 4. 5-day-old skin wound (male, 22 years, head wound)
Dermal wound area/granulation tissue. In 9 out of 25 lesions (36\%) aged less than 1.5 days a somewhat increased number of positively reacting fibroblastic cells could be observed in the wound area when compared with areas more than $0.2 \mathrm{~cm}$ distant from the wound edges or with specimens of uninjured skin. Since only a 3 -fold increase in positive cells was arbitrarily considered as an increased "staining index" (in comparison to the numbers found in parts of the specimen in a distance of more than $0.2 \mathrm{~cm}$ ) no relevantly enhanced proliferation activity could be established. Therefore, these specimens showing a slightly increased number of positive fibroblastic cells were regarded only as "questionably positive".

A 3-fold increase in the number of Ki 67 positive fibroblastic cells occurred first in a 1.5-day-old skin wound (6 positive cells per $0.01 \mathrm{~cm}^{2}$ in comparison to a maximum value of 2 cells per $0.01 \mathrm{~cm}^{2}$ in more distant areas of the dermis) and all specimens with a duration between 6 days and 1.5 months revealed positive results (maximum value 47 cells per $0.01 \mathrm{~cm}^{2}$ in a 4 -day-old head wound of a 70 years aged female). 15 out of 25 cases aged between 1.5 and 5 days $(60 \%)$ showed positive results, in $16 \%$ ( 4 out of 25 cases) a questionable result was obtained, and the remaining 6 cases $(24 \%)$ were negative.

In cases with increased amounts of $\mathrm{Ki} 67$ positive fibroblasts a rapid decrease in the number dependent on the distance from the wound edge was observed and in areas with a distance of more than $0.06 \mathrm{~cm}$ no relevantly elevated numbers could be found (Fig. 1).

A correlation between the number of $\mathrm{Ki} 67$ positive fibroblastic cells and the post-infliction interval could also not be established.

No increase in the numbers of positive cells occurred in the scar tissue of the oldest wound investigated (wound age 7 months).

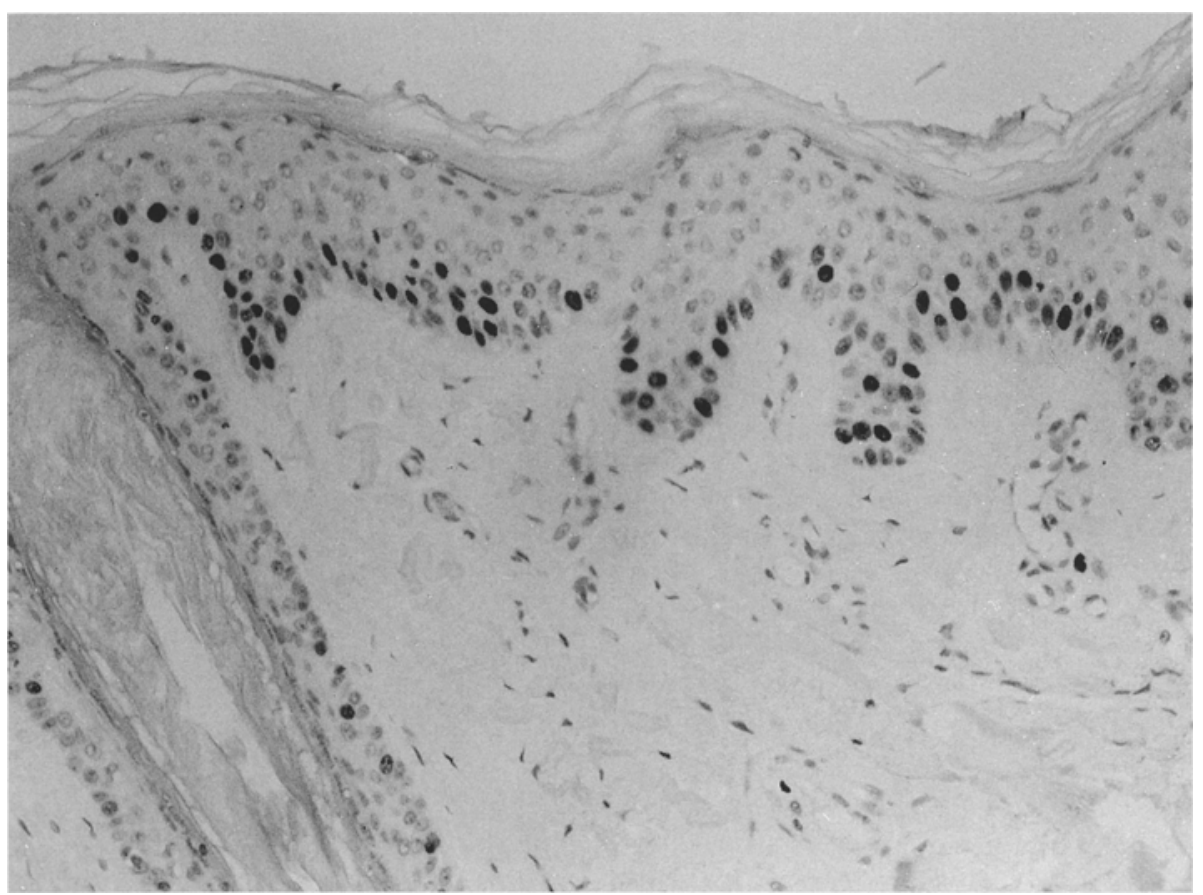

Fig. 5. Uninjured skin: epidermis and skin appendages showing numerous strongly reacting, $\mathrm{Ki} 67$ antigen positive cells in the basal cell layers (APAAP, paraffin, $190 \times$ ) 


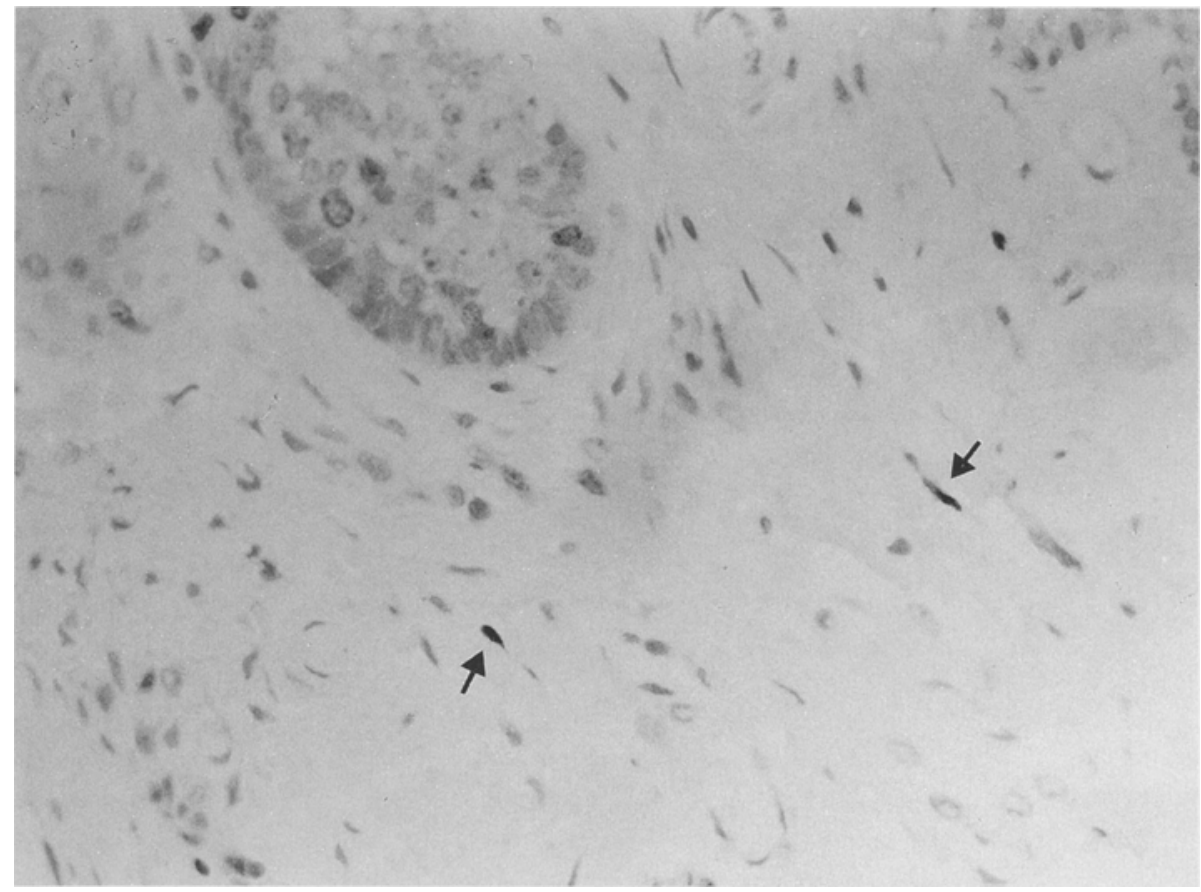

Fig. 6. 19-day-old human skin wound: positive for Ki 67 stained fibroblastic cells (see arrows) in the former wound area (APAAP, paraffin, $380 \times$ )
Relevant differences between the numbers of positively reacting epidermal basal cells or fibroblastic cells of the dermis dependent on wound localization (head, extremities or trunk) or individual age which would have exceeded the considerable variability of the results and should therefore be taken into consideration for a forensically applicable wound age estimation could not be observed.

\section{Discussion}

The monoclonal Ki67 antibody which was originally developed for studies attempting to produce an antibody specific for the nuclei or Reed-Sternberg cells, recognizes a nuclear protein found in proliferating cells. This antibody stains nuclei in the $G_{1}, G_{2}, S$, and $M$ phases of the cell cycle, while $G_{0}$ i.e. resting cells and cells entering the cycle of cell proliferation remain unstained $[10,11]$. The original antibody could be used only in cryostat sections, but the recent development [12] of a further monoclonal antibody (MIB 1) recognizing the same antigen also enables the analysis of paraffin embedded tissue. The potential of the Ki 67 antibody can be seen in defining the growth fraction of cells in human neoplasms and therefore provides considerable information on the prognosis of malignant disorders (for review see [5]).

Since cell proliferation is not only a phenomenon which can be observed in malignancies but also under certain physiological conditions such as wound healing, the use of antibodies recognizing proliferating cells can possibly be useful for a time estimation of skin wounds. However, studies dealing with the time-dependent appearance of proliferating cells recognized by this nuclear proliferating antigen have not yet been performed.
For elucidation of the advantages of such an immunohistochemical approach one has to distinguish between the reepithelialization of the epidermal lesion and the reparative changes occurring in the wound area of the dermis.

Studies dealing with the cytokinetics of epidermal cells in the healing of human skin wounds useful for a forensic wound age estimation have not been performed, but data obtained from experimental models of wound healing in animals are reported.

Epidermal wound healing starts from undamaged parts of the epidermal layer and skin appendages and areas with increased proliferation activity can be found besides regions without elevated levels of proliferating basal cells leading to a wave-like course in the number of proliferating basal cells with advancing distance from the wound margin [8]. From these areas of enhanced proliferation activity keratinocytes are moving in direction of central parts of the epidermal lesion. Block et al. [4], Hell and Cruickshank [13] and McMinn [14] described an increased proliferation activity by analysis of the ${ }^{3} \mathrm{H}$ thymidine incorporation rate on both sides of the wound margin to a distance of 300-500 basal cells i.e. 3-4 mm, but considerable differences between these authors concerning the point of time at which proliferation starts can be observed. Block et al. [4] found an increased activity after a post-infliction interval of $1 \mathrm{~h}$ in rats whereas Hell and Cruickshank [13] reported on an increased proliferation of basal cells after a wound age of $16 \mathrm{~h}$ in guinea pigs. Oehmichen and Schmidt [15] as well as Oehmichen and Lagodka [16] analyzed the incorporation of bromodeoxyuridine and of ${ }^{3} \mathrm{H}$-Cytidin in rat skin wounds and described a significant increase in the number of incorporating cells after a post-infliction interval between 10-24 h. Relevant results, however, useful for a time estimation of skin wounds could not be obtained. 


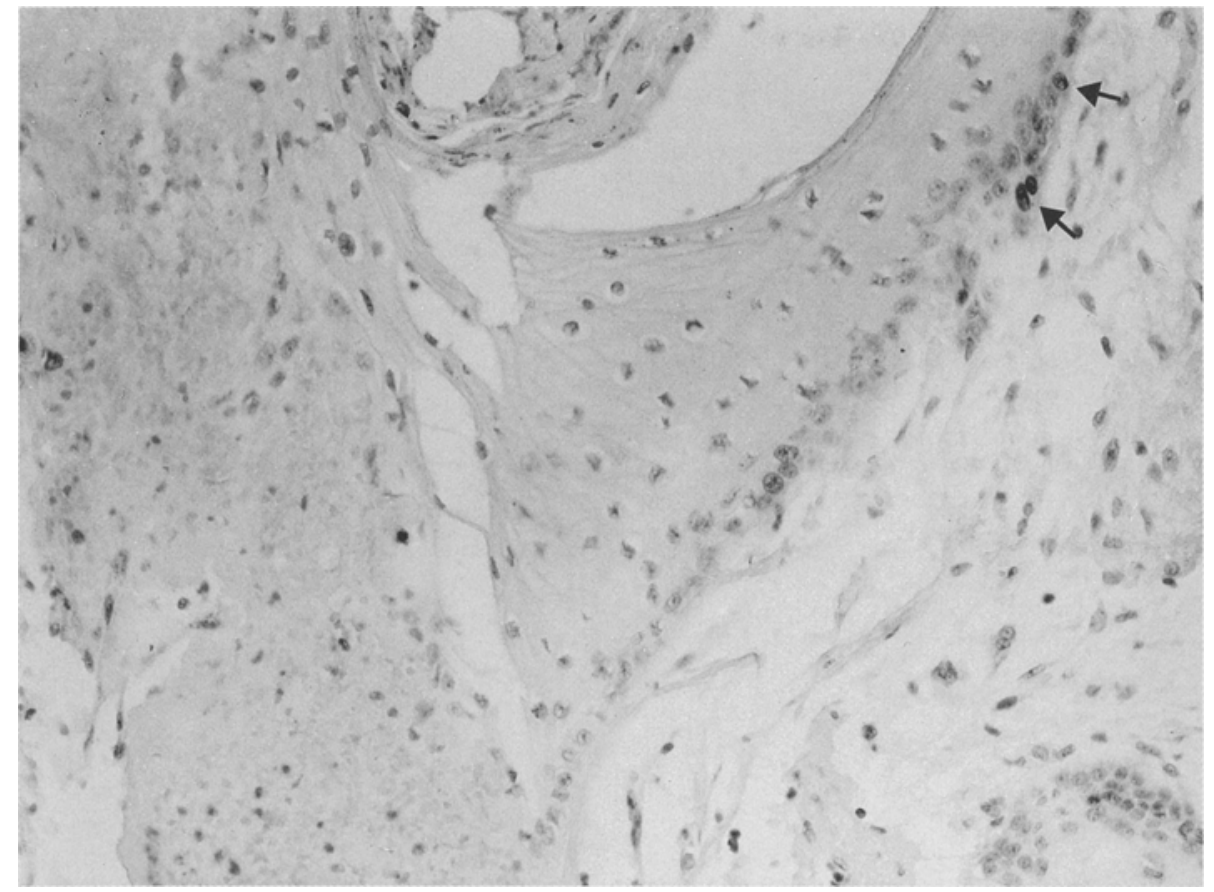

Fig. 7. 8-day-old human skin wound: no reactivity for Ki67-antigen in the basal cell layer of the newly formed epidermis; few positive nuclei of keratinocytes (see arrows) in the adjacent epidermal layer (APAAP, paraffin, $190 \times$ )
In our series, an enhanced expression of Ki 67 antigen in keratinocytes covering the previous epithelial lesion could not be established. This supports the hypothesis that keratinocyte migration which starts from areas of undamaged skin with an increased proliferation activity but not local proliferation plays the major role in reepithelialization $[2,17]$. In the epidermal layers adjacent to the wound area, however, an increased number of Ki 67 positive basal cells occurred in the most cases and a wave-like course in the numbers of proliferating basal cells with advancing distance from the wound margins could be observed according to experimental results. No reliable criterium, however, was found which may be useful for a forensically applicable time estimation of skin wounds due to the eminent intra- and interindividual variability in the numbers of positive cells found in uninjured skin and in areas considerably distant (more than $0.5 \mathrm{~cm}$ ) from the wound edges.

In the wound area/granulation tissue of the investigated skin wounds a relevant increase in the number of Ki 67 positive fibroblastic cells was observed first in a skin wound with a wound age of approximately 1.5 days and was found in all specimens aged between 6 days and 1.5 months. The observation that the number of $\mathrm{Ki} 67$ positive fibroblasts decreases rapidly with advancing distance from the wound edge indicates that only the fibroblastic cells localized in the dermis directly adjacent to the lesional area contribute to the development of the granulation tissue by proliferation.

In some skin lesions with a post-infliction interval of less than 1.5 days an increased number of positively stained cells also occurred and therefore, an earlier increase in the number of proliferating fibroblastic cells seems probable. With respect to the considerable varia- bility in the number of positive fibroblasts in undamaged dermis only a 3 -fold increase was arbitrarily regarded as a relevant positive result.

Furthermore, it must be emphasized that only those cells should be evaluated showing the typical spindleshaped morphology of fibroblastic cells since lymphocytes in cutaneous infiltrates [18] or areas of bleeding are occasionally also positively stained and it cannot be decided unambiguously in every case whether these cells have actively migrated during reparative changes or influxed passively by bleeding.

The first appearance of an increased number of Ki 67 positive fibroblastic cells in human skin wounds after a wound age of approximately 1.5 days is in good accordance with our previous results. In these studies it has been shown that myofibroblasts expressing different basement membrane components (laminin, heparan sulfate proteoglycan) can also be localized earliest approximately 1.5 days after wounding [3]. These results provide evidence that a significant increase in fibroblastic cell activity starts at this point in time. Similarly, Ross and Benditt [19], De Vito [9] as well as Cottier et al. [7] described an increase in the number of fibroblasts $24 \mathrm{~h}$ after wound infliction with a maximum after 3 days.

The immunohistochemical analysis of myofibroblasts positively stained for basement membrane components, however, possess the advantage that no positively reacting cells occur in uninjured skin under physiological conditions. On the other hand, laminin or heparan sulfate proteoglycan positive myofibroblasts cannot be regularly localized during wound healing and therefore the analysis of basement membrane positive myofibroblasts and of $\mathrm{Ki} 67$ positive fibroblastic cells can be regarded as supplementary. 


\section{Conclusion}

The immunohistochemical localization of $\mathrm{Ki} 67$ positive cells provides the following information useful for a time estimation of human skin wounds.

1. An increased number of positively reacting fibroblastic cells indicates a wound age of approximately 1.5 days or more.

2. The lack of positively reacting fibroblasts in the wound area in a sufficient number of specimens indicates a postinfliction interval of less than 6 days, but negative results should always be interpreted with care.

3. Ki 67 positive fibroblastic cells can also be found in skin wounds with advanced post-infliction intervals (in our series up to 1.5 months), but further information for the time estimation of older skin wounds cannot be obtained due to the fact that the interval in which reparative changes can be observed depends on the extent of the wound area.

4. The analysis of $\mathrm{Ki} 67$ positive basal cells of the epidermis provides no useful information for a time estimation of human skin wounds.

Acknowledgement. This study was supported by grants from the "Deutsche Forschungsgemeinschaft" (grant nos. Be 1555/1-1 and Be 1555/1-2).

\section{References}

1. Betz P, Nerlich A, Wilske J, Tübel J, Penning R, Eisenmenger W (1992) Time-dependent appearance of myofibroblasts in granulation tissue of human skin wounds. Int J Leg Med 105: 99-103

2. Betz P, Nerlich A, Tübel J, Penning R, Eisenmenger W (1993) The time-dependent expression of keratins 5 and 13 during the reepithelization of human skin wounds. Int J Leg Med 105: 229-232

3. Betz P, Nerlich A, Wilske J, Tübel J, Wiest I, Penning R, Eisenmenger W (1992) Time-dependent pericellular expression of collagen type IV, laminin, and heparan sulfate proteoglycan in myofibroblasts. Int J Leg Med 105: 169-172

4. Block P, Seiter I, Oehlert W (1963) Autoradiographic studies of the initial cellular response to injury. Exp Cell Res 30:311321
5. Brown DC, Gatter KC (1990) Monoclonal antibody Ki 67: its use in histopathology. Histopathology 17:489-503

6. Cordell JL, Falini B, Erber WN, Ghosh AK, Abdulaziz Z, MacDonald S, Pulford AF, Stein H, Mason DY (1984) Immunoenzymatic labeling of monoclonal antibodies using immune complexes of alkaline phosphatase and monoclonal antialkaline phosphatase (APAAP-complex). J Histochem Cytochem 32:219-229

7. Cottier H, Dreher R, Keller HU, Roos B, Hess MW (1976) Cytokinetic aspects of wound healing. In: Longacre JJ (ed) The ultrastructure of collagen. Thomas, Springfield/Ill, pp 108-131

8. Cottier H (ed) (1980) Pathogenese. Handbuch für die ärztliche Fortbildung. Springer, Berlin Heidelberg New York

9. De Vito RV (1965) Healing of wounds. Surg Clin North Am 45: 441-459

10. Gerdes J, Schwab U, Lemke H, Stein H (1983) Production of a mouse monoclonal antibody reactive with a nuclear antigen associated with cell proliferation. Int $J$ Cancer 31:13-20

11. Gerdes J, Lemke U, Baisch H, Wacker H-H, Schwab U, Stein H (1984) Cell cycle analysis of a cell proliferation human nuclear antigen defined by the monoclonal antibody Ki67. J Immunol 133:1710-1715

12. Gerdes J, Becker M, Key G, Cattoretti G (1992) Immunohistologic detection of tumor growth factor ( $\mathrm{Ki} 67$-antigen) in formalin fixed and routinely processed tissue. J Pathol (in press)

13. Hell EA, Cruickshank CND (1963) The effect of injury upon uptake of ${ }^{3} \mathrm{H}$-thymidine by guinea pig epidermis. Exp Cell Res 31: 128-139

14. McMinn RMM (1969) Tissue repair. Academic Press, New York London

15. Oehmichen M, Schmidt V (1988) DNS-Synthese epidermaler Basalzellen als Indikator des Wundalters. Beitr Gerichtl Med XLVI:271-276

16. Oehmichen M, Lagodka T (1991) Time-dependent RNA synthesis in different skin layers after wounding. Experimental investigations in vital and postmortem biopsies. Int J Leg Med $104: 153-159$

17. Ortonne J-P, Löning T, Schmitt D, Thivolet J (1981) Immunomorphological and ultrastructural aspects of keratinocyte migration in epidermal wound healing. Virchows Arch [A] $392: 217-230$

18. Ralfkiaer E, Stein H, Bosq J, Gatter KC, Ralfkiaer N, Lange Wantzin G, Mason DY (1986) Expression of a cell-cycle-associated nuclear antigen (Ki 67) in cutaneous lymphoid infiltrates. Am J Dermatopathol 8:37-43

19. Ross R, Benditt EP (1961) Wound healing and collagen formation. J Cell Biol 15:99-108 